\title{
A pedagogia conservadora do cinema de animação: Os Incríveis (Pixar, 2004)
}

- La pedagogía conservadora del cine de animación: Los Increíbles (Pixar, 2004)

- The Conservative Pedagogy of Animation Film: The Incredibles (Pixar, 2004)

João da Cruz Gonçalves Neto'

Resumo: Uma das mais poderosas formadoras do imaginário coletivo contemporâneo é a indústria cultural e, como produto privilegiado em termos de acesso a ele, há as animações voltadas principalmente para o público infantil produzidas por grandes estúdios de cinema, como a Pixar / Disney. Como contos de fada modernos, suas histórias remetem a belas mensagens morais, como a amizade, a solidariedade, a persistência, o respeito e outros valores edificantes, mas veiculados por mensagens políticas de força pedagógica essencialmente conservadoras ou reacionárias. Decodificar essas mensagens políticas num caso exemplar, o filme Os Incríveis, é o objetivo deste artigo. Isso será feito apresentando um resumo da trama, algumas características contextuais que formam a mensagem política e sua relação com o discurso dos direitos humanos, para ao fim postular as mensagens presumidas pela leitura moralista e pelas leituras contextual e política.

Palavras-chave: Crítica cultural. Direitos humanos Cinema de animação., Conservadorismo. Pixar.

1 Universidade Federal de Goiás, Faculdade de Direito, Núcleo Interdisciplinar de Estudos e Pesquisas em Direitos Humanos da UFG. dellacroce@dellacroce.pro.br 
Resumen: Uno de los moldeadores más poderosos del imaginario colectivo contemporáneo es la industria cultural y, como producto privilegiado en cuanto al acceso a ella, existen animaciones dirigidas principalmente a niños producidas por grandes estudios cinematográficos, como Pixar / Disney. Como los cuentos de hadas modernos, sus historias remiten a hermosos mensajes morales, como la amistad, la solidaridad, la perseverancia, el respeto y otros valores edificantes, pero transmitidos por mensajes políticos de fuerza pedagógica esencialmente conservadora o reaccionaria. Decodificar estos mensajes políticos en un caso ejemplar, la película Los Increíbles, es el propósito de este artículo. Esto se hará presentando un resumen de la trama, algunas características contextuales que configuran el mensaje político y su relación con el discurso de los derechos humanos, para finalmente postular los mensajes asumidos por la lectura moralista y por las lecturas contextual y política.

Palabras clave: Crítica cultural. Derechos humanos. Cine de animación. Conservadurismo. Pixar.

Abstract: One of the most powerful shapers of the contemporary collective imagination is the cultural industry and, as a privileged product in terms of access to it, there are animations aimed mainly at children produced by large movie studios, such as Pixar / Disney. Like modern fairy tales, their stories refer to beautiful moral messages, such as friendship, solidarity, persistence, respect and other edifying values, but conveyed by political messages of essentially conservative or reactionary pedagogical strength. Decoding these political messages in an exemplary case, the movie The Incredibles, is the purpose of this article. This will be done by presenting a summary of the plot, some contextual characteristics that form the political message and its relationship with the human rights discourse, in order to finally postulate the messages assumed by the moralistic reading and by the contextual and political readings.

Keywords: Cultural criticismo. Human rights. Animated film. Conservatism. Pixar.

\section{Introdução}

O cinema de animação produzido pela Pixar/Walt Disney Pictures possui uma importância que vai muito além do entretenimento. Possui também um papel pedagógico na formação do imaginário público mundial ainda a ser avaliado, não apenas infantil, mas também adulto. 
A Pixar, dentre outras produtoras, se destaca por criar a própria tecnologia e inovar a forma de realizar as animações, como também por usar um texto criativo, belo e com muita afinidade com a propaganda política hegemônica em grande parte do mundo - o neoliberalismo como conservadorismo.

As tramas de enorme sucesso global, ganhadoras de inúmeros Oscars e com bilheterias fenomenais, possuem comumente mensagens morais edificantes e encantadoras. Os valores da amizade, da solidariedade, da união contra a opressão, do amor familiar, da honestidade, da lealdade, da superação e do sucesso pela persistência, tanto ratificam quanto instruem nas formas de sociabilidade para uma comunidade justa e pacífica. É em torno desses valores que se situam o seu atrativo pedagógico, ainda que justiça e paz sociais sejam apenas idealizados.

Os pressupostos que conformam esses valores morais, todavia, estão implícitos nas tramas e essas são igualmente pedagógicas quando naturalizam a forma atual de organização da sociedade e quando orientam os valores morais a ratifica-la pelo heroísmo e pela identificação narrativa com o expectador.

Algumas características genéricas do pensamento conservador são aqui pressupostas pela nossa análise, sem que haja uma explicitação teórica para fundamentá-las ou justificá-las e são: as mudanças sociais devem vir pela moral, não pela política; a estrutura de poder deve ser mantida, a menos que perca sua legitimidade tradicional; há uma moral natural, senão na estrutura do universo, na estrutura partilhada da comunidade; assim, devemos preservar as formas tradicionais de comportamento moral e suas instituições equivalentes; não há, necessariamente, um futuro melhor que o passado; a sociedade é orgânica e as relações entre os indivíduos devem ser mediadas essencialmente pela moral; deve-se recusar a visão estrutural ou sociológica da sociedade; há uma tendência ao darwinismo social e a exclusão do indivíduo"inapto" deve, primeiramente, acontecer pela moral naturalizada; deve-se admitir a perda, a morte, o fracasso e a guerra dos fortes contra os fracos como um fato da vida, contra os quais pouco ou nada se pode fazer politicamente; não há multiculturalismo, mas monocultura; há a prevalência do masculinismo, da salvação pela violência e pelo heroísmo guerreiro; a tradição é mais competente que a liberdade política para gerir o destino humano; deve-se formar o espírito de comunidade, o "nós", em oposição ao outros - eles, os diferentes, os imorais, os migrantes, os sexualmente não binários, os fracos, os não crentes e outros outros; o mais forte domina o mais fraco - não há política que corrija esse dado da natureza; a recusa do intelectualismo. Essas características genéricas do conservadorismo, não problematizadas neste texto, foram extraídas de obras como as de Roger Scruton (2015: 2015), alguns aspectos da crítica social de John Gray (2004; 2011), de Michael Oakshott (1991), do neodarwinista social Jordan Peterson (2018), autor de enorme sucesso mundial, 
entre outros. Sobre o egoísmo ético, a referência principal é Ayn Rand (1992).

Para reconhecer umas ou outras dessas características do pensamento e prática política conservadoras, identificamos algumas estratégias discursivas empregadas nas tramas morais dos filmes de animação em análise: - há uma redução da complexidade social a tramas morais individuais: o que faz sentido moral ao indivíduo deve também fazer sentido social e político, isso sendo feito retirando de cena o contexto da trama como fator explicativo dos comportamentos; - a estrutura dramática é a de um ato falho: apresenta-se um fato como engraçado ou aceitável para desqualifica-lo (fala-se pelo oposto, só que voluntariamente); - a naturalização da moral e do destino humano, composto de guerra perpétua dos bons contra os maus; - o darwinismo social: os mais fracos fracassam e devem mesmo fracassar, e são estes os que exatamente se utilizarão dos argumentos políticos e estruturais como defesa; - os personagens parecem indivíduos, mas são estereótipos: os vilões são migrantes, os bandidos são latinos, os bons são os heróis másculos e brancos, o contestador político é o fracassado; - a concomitância de eras: como a moral é naturalizada, não dependente de contingências sociais, as tramas podem se desenrolar desde a pré-história até a um futuro longínquo.

Quando, neste texto, nos referimos ao reacionarismo, não o identificamos ao conservadorismo, mas apenas indicamos uma postura dogmática na política, reativa à mudança social e epistêmica, não democrática, geralmente não teorizada. Nas palavras de João Pereira Coutinho (2014, p. 24-5):

\begin{abstract}
Uma disposição política conservadora, no entanto, não recusa apenas as ambições utópicas (e futuras) dos revolucionários. Ela permite, igualmente, distinguir o conservador da sua caricatura habitual: o reacionário. Nas palavras de Anthony Quinton, o reacionário não será mais do que um 'revolucionário do avesso': alguém interessado em efetuar um corte semelhante com o 'riso presente', de forma a precipitar a sociedade, não para uma 'felicidade utópica' futura, mas para uma 'felicidade utópica' passada.
\end{abstract}

Para os propósitos deste artigo, convém retermos apenas que o reacionário exibe as características de uma psicologia radical e alimenta uma fixação num passado mítico, utópico, fantasioso.

Algumas das características teórico-ideológicas mencionadas anteriormente podem ser comuns às tramas da Pixar, outras são identificadas apenas em algumas delas. Neste artigo decodificaremos algumas mensagens políticas do filme Os Incríveis (2004), sem pretendermos esgotar, evidentemente, o quadro analítico.

\title{
Os Incríveis (2004): o elogio ao egoísmo
}


Os Incríveis, de 2004, foi o sexto filme da Pixar e também um sucesso espetacular. A película ganhou 2 Oscars das 4 indicações, além de ganhar 10, das 16 indicações, ao Annie Awards.

\section{A trama animada}

Entrevistas descontraídas em linguagem casual com os super-heróis sobre suas identidades secretas inauguram simpaticamente essa história. Eles são pessoas boas, podemos logo perceber, desprovidos de vaidade, sinceros, absolutamente altruístas, que ocupam quase seu tempo todo a salvar as pessoas comuns dos perigos nos quais elas se metem. O Senhor Incrível declara que chega a se sentir um diarista, passando o dia inteiro a limpar a sujeira que as pessoas fazem em suas relações sociais.

Na sequência temos exemplos do dia a dia de um super-herói em ação. O Senhor Incrível, em seu cotidiano atribulado, arranca uma árvore para capturar o gato que pertence a uma frágil senhorinha, ao mesmo tempo em que deve impedir a fuga de assaltantes perseguidos pela polícia. , o que consegue usando com arma a mesma árvore onde estava ainda há pouco o gatinho. Em seguida o incrível flagra um assaltante de bolsa e o algema, ajudado pela sua futura esposa, a Mulher Elástica, afirmando que o caminhão de lixo deverá recolhê-lo em uma hora, uma vez que um ladrão não é exatamente uma pessoa. Em mais uma árdua tarefa, o herói atira-se do alto de um prédio e intercepta um suicida no meio de sua queda, salvando-o da morte; ao salvá-lo, presencia o assalto de um famoso vilão francês, Bomb Voyage, quando é atrapalhado pelo seu "maior fã", o Gurincrível, um adolescente que sonha em integrar a equipe de heróis da cidade junto ao seu ídolo.

O Gurincrível, não sendo levado a sério em meio à urgência do caso, o interpela mais ou menos assim: "Você não me aceita porque não tenho superpoderes, não é? Mas nem todos os super-heróis têm superpoderes. Eu invento os meus poderes!". Quando o aspirante a herói tenta mostrar sua bota voadora, não vê que está carregando uma bomba em sua capa, retirada pelo Senhor Incrível, que a faz cair nos trilhos suspensos do metrô, provocando uma cratera prestes a engolir o trem, cuja queda é impedida prontamente pela força excepcional de seu salvador. Isso tudo momentos antes da sequência do casamento deste herói com a Mulher Elástica.

Realmente é muito difícil pensar a vida caótica na cidade sem um herói a proteger as pessoas comuns, sem os poderes necessários a enfrentar os super bandidos que são muitos, assim como a ajudar a evitar as tragédias e acidentes naturais. Se acontecem, é seguramente pela falta de heróis em nossa vida real. É por isso que seria totalmente impensável uma pessoa razoável 
questionar minimamente a importância e necessidade de pessoas tão excepcionais, superiores, abnegadas, que sacrificam suas próprias vidas para o bem comum da sociedade.

Quando a Mulher Elástica, em sua cerimônia de casamento na igreja afirma "Até que a morte nos separe, independentemente do que ocorra", o Senhor Incrivel retruca: "O que poderia nos acontecer? Nós somos super-heróis!". A partir daí nós, juntamente com eles, sofreremos ataques ao nosso senso de justiça e os acompanharemos em suas desventuras até que eles possam recuperar o seu status valorativo de superioridade natural.

O que provocará as desventuras, e que nós as viveremos também como uma injusta incompreensão das pessoas, serão as batalhas judiciais promovidas exatamente por quem foi ajudado pelos paladinos da justiça, que - por pensarem individualisticamente em seus pequenos males (uma lesão muscular, por exemplo, quando se estava prestes a morrer) - perderam o sentido do todo, do maior benefício à coletividade. Os patrocinadores dessas batalhas judiciais são aqueles que conhecemos muito por essas bandas de cá da realidade: os ativistas dos direitos humanos e do "politicamente correto". São exatamente eles; os chatos que colocam aspas com os dedos, quando pronunciam as virtudes que querem condenar; e os oportunistas que cinicamente atacam o interesse coletivo em nome de ganhos imediatos aos indivíduos.

Por conta de toda a polêmica em torno das ações dos justiceiros e o prejuízo que as condenações judiciais geraram ao Estado - acompanhada de uma intensa campanha de descrédito moral para benefício de uma assim apresentada facciosa abordagem política - os heróis foram aposentados e condenados a viverem vidas comuns, uns como burocratas, outras como donas de casa e estudantes entediados - todas pessoas sem brilho e comprimidas em seus papéis sociais.

Vemos, então, toda uma família de super talentosos - o menino Flecha, que corre tremendamente rápido; a adolescente Violeta, que tem o poder de se tornar invisível; o bebê Zezé, que possui nada menos que vinte e um super poderes, incluindo telecinese e levitação. Toda a obrigação de manterem-se "normais", numa sociedade que escolheu se nivelar por baixo, gera muito inconformismo em Beto Pêra (o Senhor Incrível), assim como nos jovens, sendo Helena (a Mulher Elástica) a única a tentar reprimir seus desejos de autenticidade dentro das expectativas determinadas pelo Estado. Flecha quer usufruir de seu poder frente a outras crianças mais lentas; Violeta, provavelmente o de seduzir seu amor com vantagens muito singulares; e Beto, o de realizar seu direito inalienável de ter um carro grande, além do de ser herói que pratica heroísmo.

Não resistindo ao poder das próprias naturezas, Beto e seu amigo Gelado começam a agir fora da lei, salvando pessoas em situações de perigo, 
submetendo-se eles mesmos ao risco intenso. Não é difícil apoiar sua contravenção quando vemos o trabalho a que Beto teve que se submeter para ser um normal. Um empregado visivelmente grande demais para o lugar que ocupava; um serviço administrativo medíocre, numa rotina tediosa, que o obriga a recusar pensões por razões contratuais levianas a velhinhas necessitadas, para promover lucros à empresa. Diante de sua recusa em convalidar a injustiça legal, Beto é chamado à presença de seu chefe baixinho e furioso, um burocrata de corpo e alma, obsessivo, que o humilha do alto de sua superioridade hierárquica, enquanto do lado de fora do prédio o mal triunfa com um ladrão agindo sem nenhum limite sobre sua vítima. Toda a cena nos comove com a desproporção - um chefe baixo, fisicamente débil, numa posição superior ao empregado alto, fisicamente trabalhado na academia de ginástica, numa posição baixa. Esse incômodo angaria a nossa revolta ao ponto de, juntamente com Beto, atirarmos seu minúsculo chefe contra a parede, para depois assumir como um herói as consequências de sua superioridade.

Essas consequências incluiriam o abandono do governo pelas altas despesas que ele promovia e a vergonha pela perda do emprego diante de sua mulher, com quem tinha uma relação um tanto infantilizada. Roberto Pêra ainda não sabia, mas a sua angústia, a baixa estima e o resgate do sentido da vida seria logo restituída. Ele foi contratado por uma organização de tecnologia experimental, para a qual poderia novamente usar seus superpoderes e sua primeira missão foi desativar um androide muito poderoso e caro, sem destruí-lo, o que realiza com sucesso e em segredo.

Seu padrão de vida melhora - ele troca finalmente de carro - fica bem mais feliz e sua autoconfiança e seu amor pela sua mulher elástica aumentam. Por dois meses a sua vida foi muito favorável até que Helena descobre a sua mentira e ele descobre que estava trabalhando para quem queria destruí-lo, o Síndrome, aquele menosprezado Gurincrível, que agora se tornara um próspero e poderoso fabricante de armas. Este anti-herói aparelhará um mesquinho ressentimento destrutivo contra todos os super-heróis - os que são bem-nascidos - com um imenso arsenal bélico, um imenso poder econômico, um incrível domínio tecnológico, para ter não mais que um simples reconhecimento dos que admira.

A aventura torna-se melhor ainda, então, pois adversários, lutas, aventuras e inimigos eram tudo o que dava sentido para o super talento do Senhor Incrível. Síndrome, aquele que venceu pela inteligência e não pela espontaneidade natural, torna-se o grande vilão, mesmo sem ter motivos aparentes para tanto, uma vez que era um super vencedor na vida, sendo admirado por todos por suas conquistas e dono de um império fabuloso de tecnologia e destruição. Como saberemos, aquele burguês enriquecido, que deseja ser um igual em nobreza, embora fazendo maravilhas criativas, jamais teria a nature- 
za de um superior, jamais teria sangue azul. E esse era o seu mal, esse era o seu ressentimento destrutivo. Ele, então, passará a ser a nova meta a triunfalmente bater, com a garantia de que os heróis devem sempre vencer.

Não será fácil, todavia. Depois de um tempo de tranquilidade e sentido, Síndrome se revela a Beto e tenta não só matá-lo, mas também humilhá-lo. O vilão consegue neutralizar o herói enquanto toda a família, excetuando o bebê Zezé, reativa os seus poderes especiais unindo-se no combate ao mal personificado. Síndrome começa um falso ataque mortal aos cidadãos usando-se de seu poderoso androide de destruição. Tudo apenas para chamar a atenção e ganhar o respeito do ídolo, que o desprezou, para então destruir a máquina e parecer aos olhos do público um legítimo herói. Só que as coisas não saem como ele planejou. A máquina foge de seu controle, torna-se verdadeiramente destrutiva, colocando ele mesmo fora de combate, o que convoca o serviço dos verdadeiros salvadores. A família Pêra, ajudado pelo amigo Gelado, depois de uma longa batalha, conseguem destruir a máquina sob os aplausos da comunidade.

Voltando a ganhar o respeito da sociedade e do Estado, com velhinhos na rua exclamando "agora tudo está bem como nos velhos tempos", a família resgata sua dignidade sem precisar mais disfarçar-se. A natureza de herói encontra o reconhecimento social de herói, e tudo fica bem.

Uma pessoa, contudo, não fica feliz - o Síndrome. O mesmo que estabeleceu para si a meta de tornar todos os indivíduos heróis para que não existissem mais heróis. Aquele que possuía o terrível vício da democracia quer vingança, e lança sua última jogada ao capturar Zezé e ameaçar novamente a família excepcional, quando é novamente derrotado. Quando todos parecem ter resgatado a tranquilidade, surge das profundezas da terra outro ser inferior que pela inveja aos bons e superiores declara guerra à paz e à tranquilidade do frágil povo. O filme acaba, então, indicando que nessa luta infindável entre o bem e o mal, entre os superiores e inferiores, entre os ressentidos igualitários e os bons por natureza jamais acabará, embora tenhamos os heróis do nosso lado, para a nossa alegria.

\section{O darwinismo social}

Poderíamos fazer uma analogia de nossos heróis, a partir de um ponto de vista moralista, com os nossos agentes da segurança pública. Temos, ali como aqui, o lema republicano da "lei e ordem" orientando a todos e aos bravos combatentes do mal, como policiais, bombeiros, forças armadas, mesmo sendo continuamente rejeitados pela população, persistindo ainda assim como heróis em sua luta abnegada, salvando gatos das alturas e gente ordinária dos bandidos. 
De um ponto de vista político, porém, os heróis podem ganhar outra roupagem. Eles seriam os industriosos, criativos, dinâmicos, geniais, percebidos nas grandes figuras empresariais, tecnológicas e financeiras. Estes seriam os vencedores por mérito em meio a uma vida humana medíocre, que sem os quais jamais sairia de sua condição dramaticamente miserável. Neste caso, a sociedade, embora reunida organicamente em torno de fins e hierarquia comuns, teria nesses Übermenschen a única forma de prosperidade, paz e tranquilidade social. Sem eles, as pessoas comuns chafurdariam na lama de sua indistinta capacidade, de sua dependência, de sua comum inferioridade.

Essa percepção política da sociedade conduz toda a trama de um dos romances mais populares nos EUA em todos os tempos, desde que foi publicado em 1957, A Revolta de Atlas, de Ayn Rand. Rand afirma que sua filosofia, "em essência, é o conceito do homem como um ser heroico, com sua própria felicidade como o propósito moral de sua vida, com a realização produtiva como sua atividade mais nobre e a razão como seu único absoluto" (RAND, 1992, p. 1170-1). Sua filosofia objetivista concebe o conhecimento e valores humanos como não sendo criados pelos pensamentos, mas antes determinados pela própria natureza da realidade.

Em A Revolta de Atlas, os heróis são os empreendedores econômicos, industriais, donos de jazidas de minérios e físicos ou engenheiros geniais, além dos competentes administradores de empresas. Eles confrontam os preguiçosos, incompetentes, não criativos, não proativos, dependentes, mesquinhos, irresolutos, líderes sindicais e políticos demagogos, que possuem em comum o fato de defenderem o igualitarismo, a democracia e a justiça social. Diante da circunstância de muitos quererem e poucos produzirem, os heróis têm de suportar todo o peso da sociedade nas costas, tal como Atlas que suporta o mundo, além de serem vítimas do ressentimento e da inveja dos inferiores. Para punir os comuns e buscar uma sociedade que lhes faça justiça por meio de uma ética perfeccionista, isolam-se numa espécie de condomínio fechado para heróis, como na Atlântida, onde se acolhia apenas os espíritos heroicos, para a infelicidade do resto da humanidade. Esta deverá, a partir de então, amargar a sua própria vida por seus próprios meios, orientada por suas baixas expectativas, corrupção, mesmice e incompetência. Para essa doutrina, o melhor seria que estes se submetessem à superioridade daqueles heróis, pois eles saberiam conduzir a vida de todos melhor que eles próprios. Próximo da tese de Rand, os nossos Incríveis (Roberto, mas também Gelado) garantem exercer um poder benevolente, submetendo-se à ordem doméstica como crianças, desde que tenham vilões lá fora para destruir.

A filosofia de Rand constitui uma influência notável na construção deste conto de fadas ultraconservador, consciente ou não. Nele podemos ver 
uma inversão da ética cristã igualitária, uma recusa aos ideais da modernidade iluminista e da democracia, um ataque violento à política como instância modeladora da vida pública. Uma vez que os nossos pensamentos e valores morais são conformados pela realidade mesma, pela natureza das coisas, seria um disparate querermos moldar a vida social por ideais transformadores. A grandeza e a pequenez moral das pessoas deverão cuidar melhor do destino coletivo, caso se tenha a sabedoria em simplesmente reconhecer o mérito de alguns poucos incríveis. Quando a sociedade (por meio do Estado) deixar de atender a esse reconhecimento, iremos de mal a pior.

Assim, não cabem paternalismos e assistencialismos quaisquer numa sociedade que pretende buscar a excelência de seus cidadãos, ainda que lhes custe a vida por inadaptação ou por desvalorização relativa. $O$ assaltante de bolsas, pego em flagrante e chamado sem meias palavras de "lixo humano", faz jus ao entendimento de que não há uma ordem estrutural prévia à moralidade, que esta se justifica por si mesma e qualquer leitura sociológica do comportamento individual é simplesmente impertinente. Os fracos, débeis, imorais, apenas perecem e somente assim a sociedade poderá melhorar, deixando os não aptos, que ocupam o lugar dos vilões, desaparecerem.

Se o demagógico discurso igualitário tem triunfado, é por conta de uma compreensão equivocada da vida social. Os contrastes no filme evocam com veemência o caráter fantasioso da igualdade frente ao que deveria ser o ideal da liberdade individual do ser superior, pelo qual nós, expectadores, também torcemos. Num momento crítico da trama, quando o Senhor Incrível já não consegue mais exercer um ofício abaixo de sua capacidade, é chamado à sala de seu chefe, contrastadamente um minúsculo homenzinho orgulhoso de seu minúsculo poder. O Incrível, com extrema facilidade, o atira pelas paredes logo após ver pela janela um assaltante cometendo impunemente seu crime e ele, o justiceiro, atado ao seu escritório sem poder fazer nada contra.

Há uma passagem no livro de Rand que se assemelha muito a essa sequência. Um alto funcionário da companhia ferroviária, Sr. Mitchum, indeciso e incompetente, pressionado por um poderoso político a lhe arranjar uma locomotiva a qualquer custo, confronta o despachante-chefe, Brent, um homem íntegro e capaz, a despachar a locomotiva mesmo sabendo de que poderá haver um terrível choque contra outra locomotiva no interior de um túnel. Este, que tem a integridade ao invés de músculos, se nega a cumprir a ordem. Eis a cena (RAND, 2010, p. 284):

- É verdade que enquanto eu ocupar este cargo não posso me recusar a obedecer a você - disse ele. Mas se eu me demitir, então eu posso. Assim, peço minha demissão. 


\begin{abstract}
- O quê?
- Peço minha demissão neste momento.

- Mas você não tem o direito de pedir demissão, seu cachorro! Não sabe disso? Não sabe que eu posso botar você na cadeia por isso?

- Se quiser, pode mandar o delegado lá em casa amanhã de manhã. Vou estar em casa. Não vou tentar fugir. Não tenho para onde ir.

Mitchum tinha 1,88 m de altura e físico de pugilista, porém tremia de fúria e terror perante a figura frágil de Brent.

- Você não pode se demitir! É proibido por lei! Não pode me largar aqui deste jeito! Não vou deixar você sair! Não vou deixar você sair deste prédio!

Brent caminhou até a porta.

- Você repete a ordem que me deu na frente dos outros? Não? Então vou embora.

Quando abriu a porta, Mitchum the acertou um soco no rosto. Brent caiu no chão.
\end{abstract}

No filme o contraste se dá na desproporção física e moral entre as personagens, sendo o vilão (o burocrata orgulhoso) inferior em ambas características, enquanto que na passagem do romance se dá entre a grandeza moral e técnica de um enfrentando a tibieza moral e força física do outro.

Sendo os heróis, moralmente concebidos, como agentes da segurança pública - injustiçados por simplesmente tentarem manter a lei e a ordem, que não compreendem - ou sendo aqueles que imporão essa ordem moral naturalizada à política, nós o acompanhamos vestindo as suas fantasias e visões de mundo. Quem não estiver com eles serão os lixos humanos, que, aliás, jamais descansam.

\title{
Os direitos humanos e o politicamente correto
}

O fato decisivo para o destino dos heróis naquela sociedade conturbada foi a chuva de ações judiciais contra as suas atuações benevolentes, num outro contraste que nos comoverá. Afinal, como poderiam ser processados aqueles que apenas agem em defesa das pessoas, são moralmente corretos e querem somente o bem público? Essa é uma ideia tão disparatada que não podemos compreender como é possível simplesmente imaginar essa possibilidade. Todavia, acontece de verdade.

A correspondência na realidade dos defensores das implausíveis "vítimas" dos salvamentos do Senhor Incrível nós não teremos dificuldade em identificar à nossa volta: são os defensores dos direitos humanos. Eles serão aqueles que, com a autoridade concedida por uma sociedade demagógica, arrogantemente invocam a lei contra os "danos" promovidos pelo salvador, mesmo quando este está em busca de um bem maior, o da sociedade e seus valores orgânicos. São eles os mesmos que, querendo inverter o nosso pretenso senso de justiça, invocam a proteção ao indivíduo, mesmo quando ele é somente um "lixo", em detrimento do bem maior da comunidade, que deseja 
uma vida tranquila, próspera e previsível.

À nossa volta estamos cansados de ver os heroicos policiais sacrificando a própria vida para a defesa da sociedade e mesmo assim sendo processados, por vezes condenados, porque mataram "lixos", como se as vidas destes valessem tanto quanto as dos agentes da força. Assim também como vemos alguns políticos bem intencionados, grandes pais e mitos da nação que não conseguem exercer o seu pleno poder por serem impedidos pelas chamadas "instituições democráticas", corruptas por natureza, em prejuízo da evolução social. Até os médicos, verdadeiros heróis que só salvam vidas e cuidam das pessoas, são frequentemente acossados pelo direito que os demagogos conferem a si mesmo de reclamarem de "danos" frente ao bem maior que sua prática pode oferecer.

Simplisticamente assim, o contraste entre os protestos obviamente equivocados e a ação justa dos heróis nos parece de fácil resolução - ficamos do lado dos nossos heróis. Caso ol hemos um pouquinho mais para o contexto dentro do qual o nosso senso de justiça é formado, a nossa percepção contrastada pode se inverter, contudo.

A primeira inversão é a da forma social. O contraste aqui está numa interpretação moral própria de uma sociedade antiga e orgânica, na qual ao invés de individualidades temos funções sociais, ou seja, pessoas cujo fim de vida é se integrar moralmente à comunidade e esta tendo apenas um objetivo comum a todos os seus componentes. O amálgama social é o compromisso moral com o todo e que sem o qual não há sentido para a vida do indivíduo, pois não há fins pessoais que possam se sobrepor aos fins coletivos.

Numa sociedade liberal moderna (a partir da referência europeia), os indivíduos, teoricamente, estariam emancipados dos fins morais comuns e cuja liberdade se expressa especialmente na forma comercial, estratégica, instrumental. Quando, portanto, sobrepomos uma expectativa orgânica sobre relações mais ou menos atomizadas, há um chamado em nós ainda duradouro para termos relações mais solidárias e fraternas, orgânicas em algum sentido, que só encontramos hoje nas igrejas e nas casernas. A projeção de uma moral pensada como se estivéssemos numa sociedade orgânica em contraste com uma moral das liberdades individuais pensada na atual sociedade fragmentada, pode conduzir-nos à simpatia pela primeira, uma vez que a solidariedade é mais atraente que a competição econômica excludente de um ponto de vista não perfeccionista.

Essa simpatia poderia ser orientada para o socialismo, exemplo máximo da incorporação da solidariedade democrática, mas nesse modelo não há heróis. É preciso que naturalizemos os talentos individuais e organizemos a sociedade para reconhecê-los. O herói, assim, não é mais que o nobre, aquele que tem sangue azul e que talento pessoal algum jamais poderá superar, 
mesmo comprando os títulos de uma possível nobreza decadente. Os heróis podem ser também os de Ayn Rand, industriais tenazes, administradores briIhantes, juízes íntegros de uma moralidade orgânica, filósofos aristotélicos, inventores geniais. Estes, no entanto, estariam mais próximos de Síndrome, que no nosso mundo incrível não obteve um lugar de respeito. Para os conservadores atuais, esses mesmos que se associaram ao neoliberalismo com refinado prazer e que podem ver em Beto apenas um estúpido marombado, a fantasia objetivista encontra um lugar de conforto.

É nesse mundo conservador-neoliberal, todavia, onde os discursos dos direitos humanos ganham mais sentido. A forma de organização social que estes imaginam como pressuposto de seus protestos e reivindicações é o mundo liberal no qual o indivíduo deve ter uma proteção mínima contra os interesses possivelmente orgânicos da sociedade, sejam eles o da eficiência econômica, o do progresso técnico, o da pacificação coletiva pela força, o da imposição pelo Estado de uma religião ou código moral únicos. Nessa sociedade pensada de um ponto de vista humanista e democrático, o uso da força e dos superpoderes para impor uma visão de mundo e um comportamento moral vinculado a uma estrutura social naturalizada recebe um nome muito particular: tirania.

Num outro confuso contraste, nessa sociedade que se pretende liberal o ideal tirânico é onipresente em filmes como este e na maior parte da produção de Hollywood. Também está presente: nas organizações empresariais; nos seus administradores que creem merecer desfrutar de uma super-riqueza correspondente aos seus supertalentos; nos médicos que creem que salvar vidas deve propiciar o reconhecimento de uma superioridade natural; nos que defendem uma sociedade militarizada, organizada na forma da rígida hierarquia, disciplina dos quartéis e apagamento das subjetividades, com um sistema educacional vocacionado para tanto; nas igrejas que colam a imagem do Satanás naqueles que não partilham de suas opiniões; no administrador público que demagogicamente adota uma política penal higienista; e no clamor popular por um salvador que nos guie em nossa inferioridade.

Os ativistas em direitos humanos, assim, a partir de um ideal liberal ou mesmo socialista, pretendem apenas defender as condições básicas para a vida em sociedade. Para tanto devem se opor aos excessos desses heróis, principalmente quando querem impor uma ordem ultra individualista, na qual o respeito às regras favorece a extração da riqueza comum pela superioridade natural, mas não a vida humana pensada comunitariamente. Pois esses heróis, quando pode parecer o contrário, não estão apenas a defender os indivíduos de suas ameaças, mas antes e principalmente, os arranjos que as produzem. E para combater os verdadeiros problemas e não seus efeitos, precisaríamos de outros heróis, não daqueles que usam seus supertalentos em favor da ordem que os beneficia. 


\section{Um outro herói}

Se há algo que o penetrante olhar raio-X dos heróis não consegue ver é a constituição dessa ordem social que pode orientar a nossa visão moral e religiosa comum. Todos os heróis são reacionários, no fim das contas. Eles fazem sentido ao codificar a nossa impotência política, a nossa incapacidade de, como na igualdade descoberta por Buzz Lightyear em Toy Story, enfrentar individualmente a violência da ordem social. Nesse contexto, a fantasia de ter superpoderes - de se distinguir dos comuns, de buscar refúgio no mundo abstrato da transcendência ou mesmo no desejo de ter uma amizade secreta com um extraterrestre - exerce um forte poder sobre nossa aspiração. Essa deseja estar acima do nível da difícil competição entre iguais, essa competição que se dá geralmente pela agressão, pela mentira, pela capacidade de super-representar a si mesmo.

Numa visão de mundo, que apenas enxerga relações morais entre indivíduos, sem mediação alguma de fatores sociais - e mesmo que se admitam fatores sociais - somente aqueles, assentados nas visões espontâneas dos indivíduos e traduzidos nas relações morais, não poderão, seguramente, admitir outra forma de heroísmo. Por outro lado, quando pensamos em características estruturais que se antecipam à visão de mundo do indivíduo e que podem, sim, estarem sujeitas à ação política, estamos a nos referir a hábitos, preferências e vieses, Com eles interpretamos a própria realidade e valores que parecem já ter nascido conosco quando na verdade foram apenas transmitidos em nossa profundidade psíquica, tudo consistindo em nossa normalidade. O herói, então, parte desse contexto, naturalizando-o, e passa a defender essa ordem habitual, sob os nossos aplausos que celebram essa ordem, quando ela nos é favorável. É nesse lugar que o herói encontra lugar em nosso peito - como alguém que partilha do incômodo de uma sociedade ameaçadora, ou como um cidadão impotente que gostaria de ter superpoderes para enfrentar os ultrajes dos quais é vítima, ou ainda como uma parte interessada em defender o seu lugar especial já constituído numa ordem destrutiva.

Mas seria possível pensarmos um outro heroísmo, não aquele de uma sociedade orgânica, constituída de algumas pessoas especiais que merecem um lugar privilegiado de superioridade natural, como nos impérios antigos? Um outro heroísmo que não o de uma sociedade ultra individualista, competitiva e excludente, cujo único modo de se conquistar uma vida decente é tendo pretensos supertalentos? Ou ainda o heroísmo que não seja o de uma sociedade atomizada cuja superioridade natural e privilégios sejam mantidos pela frágil noção de mérito pessoal, por certa hipertrofia da ordem financeira e pela violência do Estado? 
Pensar nesse novo heroísmo significa pensar num heroísmo próprio de uma sociedade igualitária e democrática. Mas é possível pensar o heroísmo num mundo de iguais, de pessoas comuns, sem poderes especiais, e onde mesmo os possíveis poderes especiais não sejam convertidos em vantagens competitivas individuais os quais o esforço de vida de todos deve servir?

A resposta da visão de mundo democrática é a de que há realmente talentos especiais, que haveriam muito mais numa sociedade mais livre e mais igualitária, e que esses talentos, descobertos ou ainda não, poderiam servir ao interesse de toda a coletividade caso ela não se apressasse em separar os que merecem o respeito público dos que vão para a lata do lixo moral e cívica, como numa determinação espontânea da natureza sobre a qual nada podemos fazer.

Caso criássemos uma história de herói que pressupusesse um contexto político diferente, como o democrático, poderíamos ter a mesma trama moral sendo desenvolvida quase sem alteração nesse outro contexto. Por exemplo: ano de 1984, num país devastado pela crise econômica, milhões de bons cidadãos, religiosos e corretos moralmente passam fome. A riqueza do povo vai sendo violentamente transferida para os muito ricos, nacionais e estrangeiros, por meio de altos preços das coisas e muitos privilégios, monopólios, leis financeiras prejudiciais à maioria da população e regras fiscais acentuadamente regressivas. Além disso, milhares tornam-se desempregados na zona rural, sem ter meios honestos de vida - eis o quadro de desolação que se pode apresentar comoventemente a nós, expectadores, como um quadro contextual a requisitar atitudes heroicas. Um homem de vida confortável, um servidor público dedicado, mas tremendamente incomodado com a situação de seu povo, consegue dar um sentido à vida de milhares de pessoas desoladas que viviam na zona rural. Ele as reune e reivindica publicamente, não no interesse individual, a terra grande e improdutiva, a terra invadida ilegalmente por grandes empresas e terras públicas sem uso à espera de grileiros, para que pudessem receber o trabalho dessa gente ansiosa por dignidade, num país o mais desigual no mundo na divisão da propriedade agrária. Afinal, se havia tanta necessidade e tanto trabalho a ser feito, não havia sentido de tantas pessoas estarem daquele jeito desesperadas. A imprensa, proprietários de terra e vários políticos, tenazes defensores do horrendo quadro que querem conservar no país, ocupariam na trama o lugar moral inverso ao dos ativistas em direitos humanos, "defensores de bandidos" por excelência. Aquele notável bandido, atuando numa trama diferente da do imaginário heroico popular, tem sido até hoje condenado como lixo social apenas por querer que as pessoas não morram de fome num país tão rico e vasto.

Ou essa outra história, na qual um educador, ao ver o imenso potencial intelectual de seu povo pobre, que sem educação ou com uma educa- 
ção orientada para diminuir o seu papel no mundo e em seu próprio país, concebe um método para educar os cidadãos como patriotas, mas com um patriotismo legítimo, solidário, com uma visão de mundo saída de sua própria experiência, aspirando por independência, autonomia, num sentido diferente das práticas que usam o mesmo nome para realizar o contrário.

E ainda uma outra trama: a da menina negra, neta de escravos, filha de lavadeira de roupas analfabeta, catadora de papel, moradora da favela, que se tornou uma escritora famosa relatando parte de sua vida até então invisível para muitas pessoas e que inspirou várias mulheres, negras e pobres, a aspirarem bem mais da vida.

Com o mesmo contexto democrático, é possível construirmos tramas cujos créditos morais mudariam de sentido mudando o lugar do protagonista, e esse lugar é o lugar político.

O herói da primeira história seria o execrado João Pedro Stédile, apresentado pela imprensa como um usurpador da lei; o herói da segunda história seria Paulo Freire, preso na Ditadura Militar por sua obra pela educação popular; a terceira heroína seria Carolina Maria de Jesus, escritora de "Quarto de despejo: diário de uma favelada", uma flor nascida num ambiente absurdamente adverso. Muitos outros heróis comuns, realizando o seu trabalho e contribuição social do alto de sua indistinção, mas orientados por um valor social atrativo comum, poderiam ser celebrados igualmente como heróis, cumprindo a desafiadora ambição de nosso líder revolucionário burguês, o Síndrome - aquele que quer que todos sejam heróis para que nenhum mais seja.

Assim, como vimos dois distintivos em especial, podem indicar a qualidade do contexto independentemente da trama moral: o lugar do protagonismo que assumimos junto às personagens e os valores atrativos da sociedade pressuposta na história. Se todos trabalhamos em prol da excelência humana e para a criação de um Olimpo, onde os melhores deverão ser servidos com manjares, vinhos e prazeres por toda a eternidade, ou se todos trabalhamos para o benefício de todos, cada um com a sua capacidade - esses são os valores políticos que decidirão a qualidade da ordem moral que produzirá seus heróis.

É comum sermos conduzidos em um protagonismo que nos atrai mais pela satisfação imaginária de nossos desejos não realizados que por refletirem a nossa posição social na vida real. Quando isso ocorre, e quase sempre ocorre, vemos as coisas com os olhos de heróis sem notarmos que somos nós, na verdade, os bandidos na trama.

Moral aparente da história

Os talentos devem ser deixados livres para servirem à coletividade governando-a, protegendo a lei e a ordem natural estabelecidas. 
Moral contextual da história

Uma boa sociedade é a que possui uma ordem incontestavelmente estabelecida e assim se realiza selecionando os bons (ou excepcionais) dos não bons (ou maus), conferindo privilégios aos primeiros e punindo, eliminando ou transformando em serviçais os segundos, na infindável guerra que é a história humana.

\section{Conclusão}

As mensagens morais dos contos de fada contemporâneos, como os realizados nos filmes do mais bem sucedido estúdio de animação do mundo, a Pixar/Disney, veiculam invariavelmente mensagens políticas conservadoras. No caso de Os Incríveis (2004) a decodificação textual nos mostra o que deve ser o mais reacionário de toda a produção daquele aclamado realizador.

A interpretação da história humana como uma guerra eterna entre o bem e o mal que utopia política alguma poderá mitigar; a naturalização dos comportamentos morais, atribuindo aos superiores, ou heróis, um lugar de privilégio numa sociedade de ideais perfeccionistas e excludentes; a assunção de uma sociedade não democrática, portanto, diante de uma hierarquização naturalizada, implicando na aceitação da seleção natural como a força motora por excelência da história; e a apresentação da trama a partir de um ponto de vista elitista com o qual todos devemos nos identificar, ainda que não seja o do nosso lugar socioeconômico, todos são pressupostos políticos que enquadram o drama moral desenvolvido na película.

As variações de conservadorismo políticos são muitas e essas são algumas características comungadas por vários teóricos. Essa aproximação teórica deve ser mais elaborada em outra ocasião. Mais que pontos de vista teóricos, contudo, muitas vezes são crenças arraigadas muito profundamente em nossa cultura, reforçadas pela produção artística comercial de massa, não apenas porque é mais lucrativo não confrontar as crenças comuns, mas porque a continuação da lucratividade depende da internalização do quadro político que a favoreça. Muitas dessas características conservadoras compartilham também algumas posições com certo ultraliberalismo, principalmente quando defendem uma elite de pessoas especiais. A primeira é definida por certa nobreza e a segunda, pelo triunfo econômico resultante da liberdade individual, além da comum recusa mais ou menos veemente dos processos democráticos.

Os Incríveis possui uma semelhança voluntária ou não com a obra de Ayn Rand, A Revolta de Atlas, uma obra de gigantesco sucesso na cultura norte-americana e que defende o ultra individualismo, o egoísmo ético e a organização social estratificada entre empreendedores valorosos com privilégios e o resto insignificante da população. Essa sonha ingenuamente que a força 
política venha a compensar a sua debilidade constitutiva. Muito desse ideário forjou e reforçou o que conhecemos como neoliberalismo, uma espécie esdrúxula de conservadorismo liberal, no qual se assume sem dificuldades os pressupostos do darwinismo social.

Este filme, portanto, é só mais um libelo em defesa deste modelo político voltado às crianças que podem internalizar a mensagem contextual, enquanto se divertem com as tensões morais resultantes da perene luta entre $o$ bem e o mal, entre nós, os heroicos reacionários, e os desprezíveis outros.

\section{Referências}

BLUMER, Herbert. Movies and Conduct. New York: MacMillan Company, 1933.

CONSTANT, Benjamin. A liberdade dos antigos comparada à dos modernos. São Paulo: Edipro, 2019.

COUTINHO, João Pereira. As ideais conservadoras explicadas a revolucionários e reacionários. São Paulo: Três Estrelas, 2014.

DARDOT, P.; LAVAL, C. A nova razão do mundo: ensaio sobre a sociedade neoliberal. São Paulo: Boitempo, 2016.

DORFMAN, Ariel; MATTELART, Armand. Para ler o Pato Donald: comunicação de massa e colonialismo. 5. ed., Rio de Janeiro: Paz e Terra, 2002.

GRAY, John. Al-Qaeda e o que significa ser moderno. Rio de Janeiro: Record, 2004.

GRAY, John. Cachorros de palha: reflexões sobre humanos e outros animais. Rio de Janeiro: Record, 2011.

KELLNER, Douglas. A cultura da mídia: identidade e política entre o moderno e o pós-moderno. Bauru/SP: Edusc, 2001.

OAKSHOTT, Michael. Rationalism in politics and other essays. Indianapolis: Liberty Fund, 1991.

PETERSON, Jordan. 12 regras para a vida: um antídoto para o caos. Rio de Janeiro: Alta Books, 2018. 
RAND, Ayn. A revolta de Atlas. São Paulo: Arqueiro, 2010.

RAND, Ayn. Atlas Shrugged. New York: Penguin, 1992.

RYAN, M.; KELLNER, D. Camera Politica: The Politics and Ideology of Contemporary Hollywood Film. Indiana: Indiana University Press, 1988.

SCRUTON, Roger. O que é conservadorismo? São Paulo: É Realizações, 2015.

SCRUTON, Roger. Como ser um conservador. 10. Ed., Rio de Janeiro: Record, 2015. 
